\title{
JURNAL TEKNODIK
}

ISSN: 2088 - 3978 e-ISSN : 2579 - 4833

Volume 23, No 1, Juni 2019

Mulai tahun 2016, terbit dua kali setahun, pada bulan Juni dan Desember

memuat pemikiran ilmiah, hasil penelitian, tinjauan, ulasan tentang Teknologi Pendidikan

Pengarah: Sekretaris Jenderal Kementerian Pendidikan dan Kebudayaan

Penanggungjawab: Kepala Pusat Teknologi Informasi dan Komunikasi Pendidikan dan

Pemimpin/

Kebudayaan

Penanggungjawab Teknis: Kepala Bagian Tata Usaha Pustekkom Kemendikbud

Dewan Penyunting: 1. Drs. Bambang Warsita, M.Pd (Teknologi Pendidikan, Pusat Teknologi Informasi dan Komunikasi Pendidikan dan Kebudayaan).

2. Dr. Purwanto, M.Pd (Teknologi Pendidikan, Pusat Teknologi Informasi dan Komunikasi Pendidikan dan Kebudayaan).

3. Dwi Sumarwanto, S.Kom., M.TI (Teknologi Informasi dan Komunikasi, Pusat Teknologi Informasi dan Komunikasi Pendidikan dan Kebudayaan).

4. Zainuddin Nasution, S.Pd., M.Si (Penelitian dan Evaluasi Pendidikan, Pusat Teknologi Informasi dan Komunikasi Pendidikan dan Kebudayaan).

5. Drs. Kusnandar, M.Pd (Teknologi Pendidikan, Pusat Teknologi Informasi dan Komunikasi Pendidikan dan Kebudayaan).

6. Dra. Andamsari, M.Si (Teknologi Pendidikan, Pusat Teknologi Informasi dan Komunikasi Pendidikan dan Kebudayaan).

7. Afidah Indranurwati, S.Pd., M.Pd (Teknologi Pendidikan, Pusat Teknologi Informasi dan Komunikasi Pendidikan dan Kebudayaan).

Mitra Bestari: 1. Dr. R. Benny Agus Pribadi, M. A. (Teknologi Pendidikan, Universitas Terbuka).

2. Prof. Dr. H. Fuad Abd. Rachman, M.Pd (Teknologi Pendidikan, Prodi Teknologi Pendidikan, Pasca Sarjana Universitas Sriwijaya).

3. Dr. Deni Darmawan, S.Pd., M.Si. (Komunikasi dan Teknologi Pendidikan, Universitas Pendidikan Indonesia).

4. Drs. Sudirman Siahaan, M.Pd (Teknologi Pendidikan, Pusat Teknologi Informasi dan Komunikasi Pendidikan dan Kebudayaan).

5. Dr. E. Oos M. Anwas (Komunikasi dan Penyuluhan Pembangunan, Pusat Perbukuan, Badan Pengembangan Bahasa dan Perbukuan, Kemendikbud).

6. Drs. Waldopo, M.Pd (Penelitian dan Evaluasi Pendidikan, Pusat Kurikulum dan Pembelajaran, Balitbang Kemendikbud).

7. Dr. Abi Sujak, M.Sc ( Pengembangan Kurikulum dan Teknologi Pendidikan, Pusat Teknologi Informasi dan Komunikasi Pendidikand dan Kebudayaan)

8. Dr. Mansur Fauzi, SE., M.Si (Teknologi Pendidikan, Pusat Teknologi Informasi dan Komunikasi Pendidikand dan Kebudayaan)

Editor Bahasa: - Harsono, S.S., M.Hum (Sastra Inggris, Linguistik Terapan, Pusat Teknologi Informasi dan Komunikasi Pendidikan dan Kebudayaan).

Administrator Laman: 1. Lukman Hakim, S.Sos., MM

2. Edhy Tua Ginulywan, S.Kom

3. Dera Permana, S.Kom

Editor Bagian: 1. Eni Susilawati, M.Pd

2. Syamsul Hadi, M.Pd

3. Puteri Ayu Febrina, S.IP

4. Rizki Utami Poetri, SE

Desain Grafis: Rusno Prihardoyo

Fasilitator: M. Yusuf Triwidodo, S.Sos

Teknisi Laman: Roni Susanto, S.Kom

Sekretariat: 1. Siti Soimah, S.Sos

2. Intan Nurlela, S.Ab 